\title{
Peran Penerapan Model Pembelajaran Asuhan Persalinan Kala I dan II Terintegrasi Terhadap Motivasi dan Kompetensi Mahasiswa serta Kepuasan Pasien pada Praktik Klinik Kebidanan
}

\author{
Sri Wahyuningsih, ${ }^{1}$ Hadi Susiarno, ${ }^{2}$ Setiawan, ${ }^{3}$ Farid Husin, ${ }^{4}$ Ishak Abdulhak, ${ }^{5}$ Firman F Wirakusumah ${ }^{6}$ \\ ${ }^{1}$ Mahasiswa Program Magister Kebidanan Fakultas Kedokteran Universitas Padjadjaran \\ ${ }^{2}$ Depertemen Obstetri dan Ginekologi Fakultas Kedokteran Universitas Padjajaran \\ ${ }^{3}$ Departemen Ilmu Faal Fakultas Kedokteran Universitas Padjadjaran RSHS Bandung \\ ${ }^{4}$ Depertemen Obstetri dan Ginekologi Fakultas Kedokteran Universitas Padjajaran \\ ${ }^{5}$ Program Studi Pengembangan Kurikulum Sekolah Pasca Sarjana Universitas Pendidikan Indonesia \\ ${ }^{6}$ Depertemen Obstetri dan Ginekologi Fakultas Kedokteran Universitas Padjajaran
}

\begin{abstract}
Abstrak
Asuhan persalinan yang diberikan bidan sesuai kebutuhan dan menyesuaikan dimensi fisiologis, psikologis, agama, budaya yang dipadukan dengan kompetensi dasar dalam asuhan persalinan. Penerapan model pembelajaran asuhan persalinan kala I dan II terintegrasi diharapkan dapat meningkatkan motivasi, kompetensi dan sesuai harapan masyarakat yaitu memberikan kepuasan pelayanan yang diberikan mahasiswa DIII Kebidanan pada praktik klinik. Tujuan penelitian ini adalah mengukur perbedaan motivasi, kompetensi mahasiswa, menganalisis hubungan motivasi dan kompetensswsi serta menganalis peranan kompetensi terhadap kepuasan pasien Metode penelitian menggunakan quasy experimental dengan one group pretest-postest design. Subyek penelitian adalah mahasiswa DIII Kebidanan semester IV Fakultas Kedokteran Universitas Negeri Sebelas Maret Surakarta, pasien yang diberi asuhan persalinan kala I dan II terintegrasi oleh mahasiswa masing masing sejumlah 37 responden dan memenuhi kriteria inklusi. Perbedaan motivasi, kompetensi dianalisis menggunakan uji Wilcoxon, uji Rank Spearman untuk menganalisis korelasi motivasi dan kompetensi (pengetahuan, sikap, ketrampilan) dengan kepuasan pasien. Hasil penelitian ini, ada peningkatan rerata nilai motivasi $40,48 \%$, pengetahuan $57,8 \%$, sikap $53,6 \%$, ketrampilan $52,47 \%$, dan kompetensi mahasiswa 64,86\% sesudah penerapan model pembelajaran asuhan persalinan kala I dan II terintegrasi. Korelasi motivasi dan kompetensi menunjukkan $\mathrm{p}>0,485$, peranan kompetensi terhadap kepuasan (variabel ketrampilan) mempunyai korelasi sedang sebesar $0,567 \quad\left(r^{2}=32,14 \%\right)$ terhadap kepuasan pasien. Simpulan dalam penelitian ini adalah terdapat peningkatan motivasi dan kompetensi motivasi dan kompetensi mahasiswa sesudah penerapan model pembelajaran asuhan persalinan kala I dan II terintegrasi, tidak ada korelasi antara motivasi dengan kompetensi mahasiswa. Kompetensi mahasiswa berperan terhadap kepuasan dengan aspek ketrampilan yang paling berperan terhadap kepuasan pasien pada praktik klinik kebidanan.
\end{abstract}

Kata kunci: Asuhan persalinan kala I dan II terintegrasi, motivasi, kompetensi, kepuasan

Korespondensi : Jl. Mahakam Gg. Yayasan No.4 RT 016, Kel Jogotrunan Kec. Lumajang Kab. Lumajang, Jawa Timur, mobile 0811353973,e-mail wahyu_ni.1978@yahoo.co.id 


\title{
The Role of Learning Care Model Application on Integrated Delivery Stage I and II toward Motivation and Competence of Students and Patients' Satisfaction to Midwifery Clinical Practice
}

\begin{abstract}
Each labor stage of a mother has different problem that requires care as needed and adjust with the dimensions of physiological, psychological, religious, cultural combined with the basic competencies of midwives on delivery care. Application of learning care models on integrated delivery stage I and II are expected to improve motivation, competence to be achieved and appropriate with expectations of society, those are provide the satisfactory services given by the DIII Midwifery students on clinical practice. Purpose of this research was to measure the difference in motivation, competency of students, analyze the relationship between motivation and kompetensswsi and analyze the role of competencies to patient satisfaction. Method of research used quasy experimental with one group pretest-posttest design. Subjects of research were the IV semester of DIII Midwifery students of Medical Faculty, Sebelas Maret University in Surakarta. The patients who were given the first and the second stage of integrated delivery care by students on the clinical practice were 37 respondents for each stage and fulfilled the inclusion criteria. The difference of motivation, the competence was analyzed by using Wilcoxon test, Rank Spearman test was used to analyze the correlation of motivation and competence (knowledge, attitude, skills) with patients' satisfaction. Research result there is an average value of increased motivation $40,48 \%, 57,8 \%$ knowledge, attitude 53,6\%,52.47\% skill, and competence $64,86 \%$ after application of learning models of care delivery stage I and II integrated. The corelation of motivation and competence is $p>0,485$, the role of competency to satisfactory with variable of skills has medium correlation toward patients' satisfactory, that is 0,567 $\left(\mathrm{r}^{2}=32,14 \%\right)$. Conclusions of this research are increased motivation and students competence after doing learning care models application of integrated delivery stage I and II, there is no corelation of motivation and students competence. Students competence contribute to satisfaction with aspect of skills that most have a role to patients' satisfaction on midwifery clinical practice.
\end{abstract}

Keywords: Delivery care stage I and II integrated, motivation, competence, satisfaction

\section{Pendahuluan}

Kompetensi yang dimiliki lulusan bidan ini berpengaruh terhadap pemberian layanan kepada masyarakat. Pertolongan persalinan di RSUD Harapan Insani Sendawar Kabupaten Kubar yang dilakukan bidan dengan standart asuhan persalinan normal (APN) masih banyak kendala, masih perlunya peningkatkan pengetahuan, sikap profesional, keyakinan dan ketrampilan bidan dalam penerapan asuhan persalinan karena kurangnya pengetahuan bidan yang berdampak pada sikap dan tindakan yang tidak sesuai standar. ${ }^{1}$ Data sekunder tahun 2014 pelayanan bidan beberapa puskesmas di Jawa Timur, Jawa Tengah, Jawa Barat, Pekan Baru, dan Padang tentang kebutuhan ibu bersalin didapatkan $98 \%$ masyarakat membutuhkan bidan yang sabar, ramah, dan dapat menjadi pendengar yang baik, serta mampu membantu menyelesaikan masalah kesehatan yang dihadapi masyarakat. ${ }^{2}$
Pelaksanaan proses pembelajaran selama ini terkotak-kotak, tidak disusun secara menyeluruh dan berkesinambungan dan kurang sesuai dengan kebutuhan ibu, menyebabkan mahasiswa tidak mampu menyelesaikan masalah secara menyeluruh dan tidak mampu menghubungkan antara pembelajaran yang sudah didapatkan selama pendidikan dengan dunia nyata sesuai permasalahan yang ada di masyarakat. ${ }^{3}$ Salah satu asuhan kebidanan yang harus dikuasai bidan yaitu asuhan persalinan komprehensif yang harus diberikan oleh bidan dimulai dari tahap awal persalinan yaitu kala I sampai kelahiran bayi. ${ }^{4}$

Peran penerapan model pembelajaran asuhan persalinan kala I dan II terintegrasi pada praktik klinik merupakan pengorganisasian kegiatan pembelajaran disesuaikan dengan kebutuhan ibu ke dalam mata kuliah asuhan persalinan. ${ }^{5}$ Tahapan tiap kala persalinan seorang ibu mempunyai permasalahan yang berbeda sehingga 
sangat membutuhkan asuhan sesuai kebutuhan dan menyesuaikan dimensi fisiologis, psikologis, agama, budaya yang dipadukan dengan kompetensi dasar bidan dalam asuhan persalinan yang diatur dalam peraturan menteri, keputusan menteri dan standar kompetensi bidan. ${ }^{6-8}$ Pembelajaran asuhan persalinan kala I dan II terintegrasi dengan menggunakan modul dilaksanakan juga pada pembelajaran klinik yang merupakan bentuk pengalaman belajar dilaksanakan pada suatu tatanan pelayanan kesehatan yang nyata, dengan menerapkan pengetahuan dan keterampilan yang diperoleh sebelumnya, sehingga memiliki sikap dan kemampuan untuk melaksanakan praktik secara mandiri, inovatif sehingga tercipta asuhan yang berkualitas. ${ }^{9}$ Praktik klinik kebidanan yang efektif merupakan salah satu hal penting dalam mengembangkan lulusan bidan kompeten dan salah satunya adalah asuhan persalinan. ${ }^{10}$ Pembelajaran asuhan persalinan kala I dan II terintegrasi yang dilakukan oleh pendidik diharapkan dapat meningkatkan kognitif atau pengetahuan mahasiswa karena sewajarnya jika mahasiswa memiliki prestasi yang kurang baik akan berusaha untuk menyiapkan dengan lebih baik dan sebaliknya mahasiswa dengan hasil yang lebih baik akan berusaha untuk mempertahankan dan meningkatkan belajarnya sehingga motivasinya juga meningkat. ${ }^{11}$

Hal ini yang menyebabkan pelayanan diberikan oleh bidan yang kompeten pada persalinan kala I dan II kepada masyarakat tidak hanya memiliki keterampilan yang baik tetapi juga mampu memberikan sikap yang baik, berkomunikasi dengan baik, memiliki rasa empati kepada masyarakat umumnya dan ibu bersalin khususnya. Berdasarkan survei pendahuluan yang dilakukan pada workshop asuhan kebidanan terintegrasi yang diikuti oleh dosen dan pembimbing klinik yang berjumlah 115 orang di Surakarta menunjukkan permasalahan yang dialami pembimbing klinik di lahan praktik yaitu mahasiswa kurang aktif dan kurang komunikatif. Harapan pembimbing klinik terhadap mahasiswa agar memberikan asuhan terhadap pasien dengan pandai, ramah, terampil, komunikatif, sopan dan disiplin. Responden menyatakan bahwa asuhan kebidanan terintegrasi perlu dilakukan guna meningkatkan kualitas lulusan sebesar $99 \%$ responden, dan 97\% responden menyatakan bahwa model asuhan kebidanan terintegrasi dapat memenuhi kebutuhan masyarakat. Pembelajaran soft skills terintegrasi ini terbukti efektif meningkatkan penguasaan tanggung jawab dan disiplin. Hal ini terjadi jika pembelajaran dilakukan melalui proses pembiasaan diikuti dengan ekpresi diri sebagai bagian dari balikan yang berfungsi untuk meneguhkan dan mendorong kearah perilaku soft skills yang sempurna. ${ }^{12}$

Ibu yang mengalami proses persalinan sangat membutuhkan asuhan dari dimensi fisiologis, psikologis, agama, budaya yang dipadukan dengan kompetensi dasar bidan. Asuhan persalinan ini diatur dalam peraturan menteri, keputusan menteri dan standar kompetensi bidan, ${ }^{8,}{ }^{13}$ sehingga asuhan persalinan terintegrasi sebagai salah satu pembelajaran terintegrasi diharapkan mampu memudahkan mahasiswa saat melakukan pembelajaran praktik klinik. Kompetensi yang hendak dicapai mahasiswa disesuaikan dengan kebutuhan ibu serta harapan masyarakat. ${ }^{6,} 14$ Asuhan persalinan kala I dan II terintegrasi yang dilakukan mahasiswa diharapkan tepat sesuai kebutuhan ibu karena mahasiswa belajar dari pengalamannya langsung dilapangan sehingga memungkinkan untuk memahami secara langsung prinsip dan konsep yang telah dipelajari sehingga kebutuhan masyarakat akan terpenuhi dan kepuasan pasien tercapai. ${ }^{6} \quad$ Secara keseluruhan, kinerja bidan dinilai baik atau memuaskan. Hal ini disebabkan karena bidan memiliki motivasi dan kompetensi yang memadai. Secara keseluruhan, kinerja bidan yang baik dipengaruhi oleh proses pendidikan yang dinilai baik. Proses pendidikan kebidanan yang ada sekarang dinilai memadai baik dilihat dari sistem pengajaran maupun dukungan sarana, salah satunya adalah pembelajaran asuhan persalinan kala I dan II terintegrasi diharapkan memberikan pelayanan yang lebih baik kepada masyarakat terutama di dalam era globalisasi. ${ }^{15}$ Tetapi angka kelulusan mata kuliah asuhan persalinan di DIII Kebidanan Fakultas Kedokteran Universitas Sebelas Maret Surakarta $60 \%$. Oleh karena itu perlu model pembelajaran asuhan persalinan kala I dan II terintegrasi yang dibutuhkan lulusan bidan untuk memenuhi kebutuhan masyarakat secara menyeluruh dan utuh.

\section{Metode}

Studi penelitian kuantitatif menggunakan quasi experimental design dengan one group pretest-posttest design. Bertujuan menganalisis 
perbedaan motivasi, kompetensi mahasiswa DIII kebidanan pada praktik klinik sebelum dan sesudah penerapan model pembelajaran asuhan persalinan kala I dan II terintegrasi. Menganalisis hubungan motivasi dan kompetensi mahasiswa pada penerapan model pembelajaran asuhan persalinan kala I dan II terintegrasi serta peranan terhadap kepuasan pasien pada praktik klinik kebidanan. Populasi dalam penelitian ini adalah mahasiswa DIII Kebidanan semester IV Fakultas Kedokteran Universitas Sebelas Maret Surakarta dan pasien yang diberi asuhan persalinan kala I dan II terintegrasi oleh mahasiswa di tempat praktik klinik. Sampel diambil dari total populasi yang berjumlah 41 mahasiswa DIII Kebidanan semester IV Fakultas Kedokteran Universitas Sebelas Maret Surakarta dan 41 pasien yang diberi asuhan persalinan kala I dan II terintegrasi oleh mahasiswa di tempat praktik klinik, memenuhi kriteria inklusi. Perbedaan motivasi, kompetensi dianalisis menggunakan uji Wilcoxon, uji Rank Spearman untuk menganalisis korelasi motivasi dan kompetensi (pengetahuan, sikap, ketrampilan) dengan kepuasan pasien. ${ }^{16}$ Penelitian akan dilakukan di Program Studi DIII Kebidanan Fakultas Kedokteran Universitas Sebelas Maret Surakarta dan institusi yang ditempati mahasiswa semester IV untuk praktik klinik kebidanan. Rencana penelitian dilaksanakan dari bulan April sampai Juli 2015.
Hasil

\section{Karakteristik Subjek Penelitian}

Karakteristik subjek penelitian pada mahasiswa adalah Indeks Prestasi Kumulatif (IPK) dan motivasi mahasiswa pada praktik klinik kebidanan sebelum dilakukan penerapan/ pengkayaan yang akan dipaparkan dalam tabel berikut ini:

\section{Tabel 1. Karakteristik IPK dan Pre Motivasi} Mahasiswa

\begin{tabular}{lll}
\hline Karakteristik & Jumlah $(n=37)$ & $\%$ \\
\hline
\end{tabular}

\begin{tabular}{lcc} 
1. IPK & & \\
Sangat Baik & 3 & 8,1 \\
Baik & 22 & 59,5 \\
Cukup & 8 & 21,6 \\
Kurang & 4 & 10,8 \\
2. Motivasi & & \\
Tinggi & 11 & 29,7 \\
Rendah & 26 & 70,3 \\
\hline
\end{tabular}

Tabel 1 menunjukkan Indeks Prestasi Kumulatif (IPK) mahasiswa semester IV sebagian besar adalah baik $(3,01-3,50)$ dan sebagian besar motivasi mahasiswa pada praktik klinik sebelum pengkayaan adalah rendah.

2. Motivasi Mahasiswa Sebelum dan Sesudah Penerapan Model Pembelajaran Asuhan Persalinan Kala I dan II Terintegrasi

Hasil analisis motivasi mahasiswa sebelum dan sesudah penerapan model pembelajaran asuhan persalinan kala I dan II terintegrasi.

Tabel 2 Perbedaan Motivasi Mahasiswa Sebelum dan Sesudah Penerapan Model Pembelajaran Asuhan Persalinan Kala I dan II Terintegrasi

\begin{tabular}{lccc}
\hline \multicolumn{1}{c}{ Variabel } & Sebelum & Sesudah & Nilai p \\
\hline Motivasi & & & \\
Median (rentang) & $52(42,7-84)$ & $76(72-92)$ & $<0,001)^{*}$ \\
Mean (SD) & $57,76(12,59)$ & $77,8(4,59)$ & \\
\hline
\end{tabular}

Ket. *) Uji Wilcoxon

Tabel 2 menunjukkan nilai rerata motivasi mahasiswa lebih tinggi sesudah diberi penerapan asuhan persalinan kala I dan II terintegrasi. Hasil uji Wilcoxon $(\mathrm{p}=0,000)$ terdapat perbedaan yang bermakna. Penerapan model pembelajaran asuhan persalinan kala I dan II terintegrasi meningkatkan motivasi
3. Kompetensi Mahasiswa Sebelum dan Sesudah Penerapan Model Pembelajaran Asuhan Persalinan Kala I dan II Terintegrasi pada Praktik Klinik Kebidanan

Pengujian nilai sebelum dibandingkan dengan sesudah penerapan model pembelajaran asuhan persalinan kala I dan II terintegrasi untuk mengetahui kebermaknaan perbedaan pencapaian 
nilai pengetahuan, sikap, ketrampilan dan kompetensi pada praktik klinik kebidanan

Tabel 3 Perbedaan Kompetensi Mahasiswa Sebelum dan Sesudah Penerapan Model Pembelajaran Asuhan Persalinan Kala I dan II Terintegrasi pada Praktik Klinik Kebidanan

\begin{tabular}{lccc}
\hline Variabel & Sebelum & Sesudah & Nilai p \\
\hline Kompetensi & 37 & 13 & \\
Tidak Kompeten & 0 & 24 & \\
Kompeten & & & \\
$\quad$ Pengetahuan & $50(45-60)$ & $85(60-100)$ & $0,000^{*}$ \\
$\quad$ Median (rentang) & $52,56(4,94)$ & $82,83(8,86)$ & \\
$\quad$ Mean (SD) & & & \\
Sikap & $60(60-80)$ & $100(60-100)$ & $0,000^{*}$ \\
$\quad$ Median (rentang) & $62,16(6,29)$ & $94,59(11,20)$ & \\
$\quad$ Mean (SD) & & & \\
$\quad$ Ketrampilan & $60(60-80)$ & $100(60-100)$ & $0,000^{*}$ \\
$\quad$ Median (rentang) & $62,72(6,93)$ & $94,59(10,16)$ & \\
$\quad$ Mean (SD) & & & \\
\hline
\end{tabular}

Ket. *) Uji Wilcoxon

Tabel 3 menunjukkan pengetahuan lebih baik, sikap lebih positif, ketrampilan lebih terampil, kompetensi lebih kompeten sesudah penerapan model pembelajaran asuhan persalinan kala I dan II terintegrasi, dengan uji Wilcoxon menunjukkan perbedaan bermakna masingmasing $\quad(p=0,000)$. Penerapan model pembelajaran asuhan persalinan kala I dan II terintegrasi meningkatkan kompetensi mahasiswa (pengetahuan, sikap, ketrampilan

4. Motivasi dan Kompetensi Mahasiswa pada Penerapan Model Pembelajaran Asuhan Persalinan Kala I dan II Terintegrasi

Analisis korelasi antara motivasi dengan kompetensi mahasiswa disajikan dalam tabel berikut.

Tabel 4 Korelasi Motivasi dan Kompetensi (Pengetahuan, Sikap, Ketrampilan)

\begin{tabular}{lcccc}
\hline Variabel & Kompetensi & Pengetahuan & Sikap & Ketrampilan \\
\hline Motivasi & & & & \\
Nilai r & 0,113 & 0,048 & 0,208 & 0,181 \\
Nilai p & 0,507 & 0,780 & 0,217 & 0,282
\end{tabular}

Ket. *) Uji Spearman

Tabel 4 menunjukkan tidak adanya korelasi yang bermakna antara variabel motivasi dengan kompetensi mahasiswa $(\mathrm{p}>0,05)$.

\section{Kompetensi Mahasiswa Terhadap Kepuasan Pasien pada Praktik Klinik Kebidanan}

Tabel 5 Kompetensi Mahasiswa Terhadap Kepuasan Pasien

\begin{tabular}{lcccc}
\hline Variabel & Kompetensi & Pengetahuan & Sikap & Ketrampilan \\
\hline Kepuasan & & & & \\
Nilai r & $0,466^{* *}$ & 0,310 & $0,506^{* *}$ & $0,567^{* *}$ \\
Nilai p & 0,004 & 0,062 & 0,001 & 0,000 \\
$r^{2}$ & $21,7 \%$ & $9,61 \%$ & $25,6 \%$ & $32,14 \%$ \\
\hline Ken & & &
\end{tabular}


Tabel 5 menunjukkan peranan/ keeratan yang sedang pada sikap, ketrampilan, tetapi lemah pada pengetahuan. Ketrampilan mahasiswa memberikan peranan yang paling besar terhadap kepuasan pasien pada praktik klinik kebidanan setelah mendapatkan pembelajaran asuhan persalinan kala I dan II terintegrasi $(32,14 \%)$.

\section{Pembahasan}

\section{Karakteristik Subjek Penelitian}

Berdasarkan hasil analisis karakteristik bahwa Indeks Prestasi Kumulatif (IPK) pada semester III, 22 dari 37 mahasiswa dengan kriteria baik $(3,01-3,50)$. Hal ini menunjukkan kemampuan prestasi yang merata untuk mahasiswa DIII Kebidanan semester IV. 26 dari 37 mahasiswa menunjukkan motivasi rendah pada praktik klinik sebelum pengkayaan. Motivasi yang rendah ini memerlukan pembelajaran yang efektif, sesuai harapan mahasiswa untuk memperoleh manfaat seperti yamg dicita-citakan, hal ini juga ditentukan oleh kemampuan dosen dan mahasiswa serta lingkungan yang kondusif. ${ }^{17}$

2. Motivasi Mahasiswa Sebelum dan Sesudah

Penerapan Model Pembelajaran Asuhan Persalinan Kala I dan II Terintegrasi

Model pembelajaran terintegrasi merupakan pengintegrasian berbagai disiplin ilmu dan bisa diterapkan mulai dari pembelajaran di kelas, laboratorium sampai pada pasien langsung atau praktik klinik mahasiswa. Pendidikan kedokteran membuktikan pelaksanaan pembelajaran terintegrasi terhadap peningkatan minat belajar, mengurangi duplikasi pada materi kuliah, meningkatkan komunikasi, pemahaman pelayanan berpusat pada pasien. ${ }^{18}$ Model pembelajaran terintegrasi di praktik klinik lebih banyak diterapkan oleh pendidikan kedokteran. Hal ini berperan terhadap peningkatan motivasi praktik klinik mahasiswa yaitu $78 \%$ percaya untuk tampil lebih baik, 60\% apresiasi terhadap pemahaman pengetahuan, komunikasi dan penerapan ketrampilan dasar. ${ }^{14}$ Pembelajaran terintegrasi mengkolaborasikan multidisiplin ilmu, dapat menghindari pengulangan materi yang tidak perlu, pendekatan dalam mengajar tidak terputus-putus sehingga dapat menghindari kebingungan dalam pikiran mahasiswa yang mengarah ke kegagalan menangkap subjek secara keseluruhan. ${ }^{19}$ Oleh karena itu dengan pembelajaran asuhan persalinan kala I dan II terintegrasi yang dilakukan oleh pendidik dapat meningkatkan kognitif atau pengetahuan mahasiswa karena sewajarnya jika mahasiswa memiliki prestasi yang kurang baik akan berusaha untuk menyiapkan dengan lebih baik dan sebaliknya mahasiswa dengan hasil yang lebih baik akan berusaha untuk mempertahankan dan meningkatkan belajarnya. ${ }^{11}$

Penerapan model pembelajaran asuhan persalinan kala I dan II terintegrasi ini juga membuktikan adanya peningkatan motivasi mahasiswa DIII Kebidanan dalam mempersiapkan diri dan melaksanakan praktik klinik kebidanan, tetapi karena pembelajaran asuhan persalinan telah selesai dilaksanakan, maka penerapan model pembelajaran ini di luar jam kuliah (ekstrakulikuler) selama 4 minggu. Berdasarkan tabel 2 peningkatan rerata nilai motivasi setelah penerapan model pembelajaran asuhan persalinan kala I dan II terintegrasi dilakukan pengkayaan dengan model pembelajaran asuhan persalinan kala I dan II terintegrasi sebesar $40,48 \%$. Hasil uji statistika menunjukkan terdapat perbedaan motivasi yang bermakna $(p=0,000)$ sebelum dan sesudah penerapan model pembelajaran asuhan persalinan kala I dan II terintegrasi. Motivasi mahasiswa yang tinggi sejumlah 11

(pre motivasi) menjadi 37 (post motivasi) mahasiswa.

Peningkatan motivasi mahasiswa setelah pengkayaan bisa disebabkan adanya pembelajaran yang efektif menggunakan metode pembelajaran dengan menyertakan praktikum (studi kasus) dalam proses pembelajaran. Pembelajaran kasus ini akan menimbulkan semangat dan kegembiraan dari mahasiswa karena percaya akan mendapatkan sesuatu yang baru dan menarik. ${ }^{20}$ Perhatian mahasiswa terhadap pembelajaran ini ditunjukkan dengan antusias dalam menyelesaikan tugas-tugas yang diberikan, pembelajaran mengaitkan materi dan kegiatan belajar dengan kehidupan sehari-hari sehingga kepercayaan mahasiswa ${ }^{21}$ dalam melakukan tindakan pertolongan persalinan kala I dan II juga meningkat, dan ditunjang juga kehadiran mahasiswa dalam mengikuti pembelajaran terintegrasi sampai selesai yaitu 37 dari 41 mahasiswa. Kurikulum di Program Studi DIII Kebidanan salah satunya adalah mengikuti praktik klinik kebidanan yang merupakan kewajiban bagi mahasiswa dan merupakan 
motivasi ekstrinsik dalam rangka menerapkan teori dan konsep-konsep kebidanan yang didapat saat pembelajaran di kelas. ${ }^{22}$ Motivasi dapat mendorong seseorang untuk mencapai tujuan tertentu yang juga tercakup konsep-konsep seperti kebutuhan untuk berprestasi, kebutuhan beraktifitas, kebiasaan, keingintahuan terhadap sesuatu. ${ }^{23}$ Motivasi juga merupakan energi dalam proses pembentukkan kompetensi (menurut Skinner dan Elliot).

3. Kompetensi Mahasiswa Sebelum dan Sesudah Penerapan Model Pembelajaran Asuhan Persalinan Kala I dan II Terintegrasi pada Praktik Klinik

Model pembelajaran terintegrasi pada pembelajaran kelas maupun laboratorium telah dilakukan oleh pendidikan kesehatan. Hasil peningkatan $78 \%$ pemahaman sesuai kasus nyata sehingga mampu mengembangkan ketrampilan untuk menganalisis pada motivasi dan kompetensi mahasiswa kedokteran. ${ }^{24}$ Penerapan model pembelajaran asuhan persalinan kala I dan II terintegrasi ini meningkatkan pengetahuan mahasiswa $57,8 \%$, sikap mahasiswa $53,6 \%$, ketrampilan mahasiswa 52,47\%.

Penerapan model pembelajaran terintegrasi meningkatkan kemampuan mahasiswa dalam memberikan pelayanan yang berbasis komunitas dan terbiasa mempelajari suatu pengetahuan berdasarkan konteks nyata sehingga ketika praktik klinik atau pembelajaran di komunitas mampu beradaptasi dan mengaplikasikannya. ${ }^{25}$ Pembelajaran terintegrasi mengkolaborasikan beberapa mata kuliah, dapat menghindari pengulangan materi yang tidak perlu, pendekatan dalam mengajar tidak terputus-putus sehingga dapat menghindari kebingungan dalam pikiran mahasiswa yang mengarah ke kegagalan menangkap subjek secara keseluruhan. ${ }^{19}$ Oleh karena itu dengan pembelajaran asuhan persalinan kala I dan II terintegrasi yang dilakukan oleh pendidik dapat meningkatkan kognitif atau pengetahuan mahasiswa karena sewajarnya jika mahasiswa memiliki prestasi yang kurang baik akan berusaha untuk menyiapkan dengan lebih baik dan sebaliknya mahasiswa dengan hasil yang lebih baik akan berusaha untuk mempertahankan dan meningkatkan belajarnya. ${ }^{11}$ Model pembelajaran terintegrasi memberi keleluasaan kepada mahasiswa untuk menggali pengetahuan di berbagai variasi materi terkait aspek-aspek dalam lingkungan yang nyata. ${ }^{19}$

Tabel 3 menunjukkan perbedaan yang bermakna $(\mathrm{p}=0,000)$ dengan peningkatan rerata nilai pengetahuan $57,8 \%$. Mahasiswa yang sebelumnya $100 \%$ menjadi $8,1 \%$ yang mempunyai nilai 70 setelah penerapan model pembelajaran ini. Masih adanya mahasiswa yang mempunyai nilai di bawah 70 disebabkan karena pembelajaran di kelas untuk mata kuliah asuhan persalinan bagi mahasiswa DIII Kebidanan semester IV ini telah dilaksanakan, karena itu penerapan model pembelajaran asuhan persalinan dilakukan di luar jam pelajaran. Penerapan model pembelajaran ini lebih di fokuskan untuk praktik klinik, sehingga pembelajaran yang diberikan kurang maksimal. Penerapan pembelajaran terintegrasi sesuai dengan tuntutan masyarakat untuk meningkatkan mutu pendidikan secara menyeluruh yakni aspek-aspek moral, akhlak, budi pekerti, perilaku, pengetahuan, kesehatan, ketrampilan dan seni. ${ }^{19}$ Pembelajaran soft skills terintegrasi ini terbukti efektif meningkatkan penguasaan tanggung jawab dan disiplin. Hal ini terjadi jika pembelajaran dilakukan melalui proses pembiasaan diikuti dengan ekpresi diri sebagai bagian dari balikan yang berfungsi untuk meneguhkan dan mendorong kearah perilaku soft skills yang sempurna. ${ }^{12}$ Rerata nilai sikap mahasiswa menunjukkan peningkatan 53,6\% setelah penerapan model pembelajaran. Sebelum penerapan model pembelajaran ini, $100 \%$ mahasiswa menunjukkan kurangnya sikap sopan, santun menghormati pasien, mengerjakan sesuatu dengan hati-hati, teliti, kemampuan merespon ekspresi dari orang lain, tetapi setelah penerapan model pembelajaran ini turun 21,6\%. Masih adanya sikap negatif mahasiswa ini disebabkan karena kurangnya pengalaman menolong persalinan, mahasiswa belum ada yang menikah, kurangnya respon terhadap ekspresi orang lain, kurangnya membiasakan diri untuk berempati dengan orang lain yang menyebabkan penilaian kurang sesuai dengan harapan pasien.

Standar kompetensi bidan bertujuan untuk mempersiapkan bidan menjadi tenaga kesehatan profesional, kompeten secara intelektual, memiliki tanggung jawab sosial, bersahabat dalam memenuhi kebutuhan kesehatan bagi individu, keluarga, kelompok dan masyarakat. ${ }^{6}$ Pembelajaran terintegrasi memberi kesempatan mahasiswa dapat memilih kegiatan 
kelompok kecil maupun mandiri dan kesempatan bagi mahasiswa berinisiatif sendiri, melakukan keterampilan atas prakarsa sendiri sebagai aktivitas yang dipilihnya. ${ }^{19}$ Pembelajaran terintegrasi pada mahasiswa kedokteran di India menunjukkan prestasi yang lebih baik serta mahasiswa lebih memahami dalam mengaplikasikan pengetahuan ke dalam praktik kedokteran. $^{14}$ Penilaian ketrampilan pada penelitian ini dilakukan bersamaan dengan sikap ketika mahasiswa melakukan pertolongan persalinan kala I dan II terintegrasi di praktik klinik, pada tabel 3 menunjukkan rerata nilai terdapat peningkatan rerata nilai ketrampilan $52,47 \%$. Ketrampilan sebelum pengkayaan $100 \%$ kemampuan melakukan prosedur tindakan tidak sesuai standar operasional prosedur yang ada (modul asuhan persalinan kala I dan II terintegrasi), setelah menerapan turun menjadi $24,32 \%$. Hal ini disebabkan karena kurangnya pengalaman menolong persalinan, pembelajaran asuhan persalinan kala I dan II terintegrasi yang hanya dilakukan selama 6 kali masing- masing pertemuan 100 menit yang dibagi dalam pembelajaran kelas, pembelajaran di laboratorium menyebabkan pembiasaan diri menggunakan modul persalinan kala I dan II terintegrasi belum maksimal.

Salah satu bahan pembelajaran yang digunakan dalam pendekatan pembelajaran mandiri dan sesuai dengan pembelajaran terintegrasi adalah modul. ${ }^{26} \mathrm{Hal}$ ini semakin menunjang dalam pelaksanaan evaluasi praktik klinik yang dilakukan oleh pembimbing praktik dan memudahkan mahasiswa dalam mengaplikasikan pengetahuan yang didapat di kelas ke dalam tatanan nyata baik bersikap maupun tindakan. Ibu yang mengalami proses persalinan sangat membutuhkan asuhan dari dimensi fisiologis, psikologis, agama, budaya yang dipadukan dengan kompetensi dasar bidan dalam asuhan persalinan yang diatur dalam peraturan menteri, keputusan menteri dan standar kompetensi bidan, ${ }^{8,13}$ sehingga asuhan persalinan terintegrasi sebagai salah satu pembelajaran terintegrasi diharapkan mampu memudahkan mahasiswa saat melakukan pembelajaran praktik klinik sesuai kompetensi yang hendak dicapai dan sesuai dengan kebutuhan ibu serta harapan masyarakat. ${ }^{6,14}$

\section{Motivasi dan Kompetensi Mahasiswa pada Penerapan Model Pembelajaran Asuhan Persalinan Kala I dan II Terintegrasi terhadap Kepuasan Pasien pada Praktik Klinik Kebidanan}

Kurikulum di DIII Kebidanan salah satunya adalah mengikuti praktik klinik kebidanan yang merupakan kewajiban bagi mahasiswa dalam rangka menerapkan teori dan konsep-konsep kebidanan yang didapat saat pembelajaran di kelas. $^{22}$ Indeks Prestasi Kumulatif (IPK) mahasiswa menunjukkan tidak adanya hubungan dengan kompetensi mahasiswa. Hal ini menunjukkan kemampuan mahasiswa adalah sama pada saat penerapan pembelajaran asuhan persalinan kala I dan II karena pengkayaan yang diberikan adalah hal baru yang diterima mahasiswa. Tabel 4 menunjukkan motivasi tidak berkorelasi dengan kompetensi mahasiswa $(\mathrm{p}>0,05)$. Hal ini menunjukkan bahwa pada penelitian ini, peningkatan pada motivasi setelah penerapan model pembelajaran asuhan persalinan kala I dan II terintegrasi tidak berhubungan dengan adanya peningkatan kompetensi mahasiswa pada praktik klinik kebidanan.

Faktor yang mempengaruhi kompetensi banyak sekali, diantaranya efektifnya lingkungan pendidikan yang memfasilitasi belajar mengajar pada saat di kelas, laboratorium maupun tempat praktik. Lingkungan klinis yang efektif dalam pembelajaran praktik klinik dapat mempengaruhi kompetensi mahasiswa. Lingkungan klinis mencakup semua yang ada di praktik klinik termasuk pengaturan jadwal dinas, peralatan, petugas, pasien dan dosen. ${ }^{27}$ Penelitian di kedokteran Iran 60,6\% dari 66 responden menyatakan bahwa lingkungan klinis yang baik yaitu menghargai dan memberi kesempatan yang tepat untuk belajar dalam rangka memenuhi tujuan mahasiswa. Lingkungan belajar yang mendukung untuk mengkonsolidasikan pengetahuan, keterampilan mahasiswa dengan memberi kesempatan secara aktif ikut menangani pasien, hal ini dapat meningkatkan kompetensi mahasiswa. Penelitian di Kedokteran Iran 68,8\% responden mengatakan perlunya pengawasan pembimbing, 53,1\% mengatakan perlu diberikan waktu yang cukup dalam praktik klinik.

Faktor lain yang memengaruhi peningkatan kompetensi yaitu frekuensi atau waktu pembelajaran klinik ini sudah dilakukan lebih 
dari sekali, sehingga pemahaman dan perubahan keyakinan siswa dalam pengetahuan, komunikasi dengan pasien serta ketrampilan menjadi lebih baik. Peningkatan usia mahasiswa, waktu, pengalaman praktik klinik sebelumnya (lebih dari sekali) dalam penelitian ini menunjukkan korelasi positif terhadap kemampuan dalam keterampilan komunikasi klinis dengan pasien. ${ }^{28}$

Tabel 5 kompetensi menunjukkan peranan/ keeratan yang sedang pada sikap, ketrampilan, tetapi lemah pada pengetahuan. Ketrampilan mahasiswa memberikan peranan yang paling besar terhadap kepuasan pasien pada praktik klinik kebidanan setelah mendapatkan pembelajaran asuhan persalinan kala I dan II terintegrasi $(32,14 \%)$. Penilaian kepuasan pasien ini diukur setelah mahasiswa melakukan pertolongan persalinan kala I dan II menyesuaikan tempat praktik mahasiswa, sehingga adakalanya mahasiswa juga melakukan tindakan kebidanan yang lain selain memberikan asuhan persalinan kala I dan II terintegrasi. Hal ini memberikan dampak bervariasi pada penilaian kepuasan pasien terhadap pelayanan oleh mahasiswa.

Pernyataan kepuasan dari pasien yang pertolongan persalinan kala I dan II dilakukan oleh mahasiswa sesuai dengan kuesioner, sebagian besar dari pasien untuk kepuasan umum setuju bahwa mahasiswa memberi informasi mengenai tindakan pertolongan persalinan dengan jelas. Hal ini terkait dengan kemampuan pengetahuan/ kognitif yang didapatkan mahasiswa berdasarkan teori persalinan. Kompetensi mahasiswa pada kemampuan kognitif mampu membangun pengetahuan dasar terutama pada saat memberikan informasi kepada pasien.

Kemampuan kualitas teknik mahasiswa (pengetahuan) pasien menyatakan setuju mengikuti saran yang diberikan oleh mahasiswa karena mereka menangani setiap keluhan yang dirasakan dengan benar. Kemampuan kualitas teknik (sikap) sebagian besar pasien menyatakan mahasiswa menunjukkan sikap bersahabat pada saat melakukan pertolongan persalinan. Kemampuan kualitas teknik (ketrampilan) mahasiswa telah menyiapkan peralatan yang diperlukan untuk pertolongan persalinannya, melakukan pemeriksaan dengan hati-hati, teliti. Mahasiswa menjelaskan semua tindakan tentang persalinan tetapi masih ada pasien yang merasa cemas karena ada sebagian mahasiswa yang tampak kurang terampil.

Kompetensi mahasiswa, komitmen dosen, pembimbing klinik, anggota tim lain dalam menghadapi pasien menyebabkan kepuasan yang dirasakan petugas kesehatan dan pasien. Hubungan interpersonal (bagian dari sikap pada kompetensi) diidentifikasi sangat signifikan dalam lingkungan belajar klinis. ${ }^{27}$ Pembelajaran ini berperan dalam peningkatan etika saat praktik klinik, peningkatan kemampuan berkomunikasi saat menghadapi pasien yang didukung adanya peranan sikap mahasiswa. Kemampuan interpersonal (sikap) mahasiswa yang dirasakan pasien menyebabkan kepuasan diantaranya perhatian terhadap keluhan yang dirasakan, hormat, mampu menjaga rahasia selama melakukan pertolongan persalinan, ramah. Kemampuan mahasiswa yang masih dirasakan kurang memuaskan pada sebagian pasien karena mahasiswa kurang merespon yang disampaikan pasien dan kaku saat menolong persalinan.

Kemampuan komunikasi mahasiswa pada kompetensi pengetahuan sebagian besar menyatakan mahasiswa menggunakan bahasa yang mudah dimengerti dan dipahami saat menjelaskan, memberi kesempatan untuk bertanya tentang kondisi pasien serta menjelaskannya sesuai kebutuhan. Kemampuan bersikap ditunjukkan dengan memberi perhatian penuh dan kesempatan bertanya tentang proses persalinan yang dialami. Ketrampilan berkomunikasi ditunjukkan mahasiswa pada saat menolong persalinan menjelaskan setiap tindakan yang dilakukan dengan jelas dan menggunakan bahasa yang mudah dimengerti. Kemampuan komunikasi yang baik dapat memungkinkan mahasiswa memberikan perawatan berpusat pada kebutuhan pasien. Keterampilan mendengarkan aktif, belajar menggunakan literatur berbasis bukti dan berpikir kritis, tetapi untuk kepuasan yang berhubungan dengan waktu pelayanan masih dirasakan pasien kurang. Hal ini menyebabkan mahasiswa harus bisa mengevaluasi dan menetapkan prioritas strategi perawatan terhadap pasien. ${ }^{29}$

Kesempatan pada mahasiswa dalam memberikan pelayanan, otonomi menjalankan pelayanan kepada pasien secara profesional yaitu terkait kreatifitas dan seni yang digunakan mahasiswa dalam praktik klinik, mendengarkan pasien, mengurangi nasehat dapat meningkatkan 
Sri Wahyuningsih : Peran Penerapan Model Pembelajaran Asuhan Persalinan Kala I dan II Terintegrasi Terhadap Motivasi dan Kompetensi Mahasiswa serta Kepuasan Pasien pada Praktik Klinik Kebidanan

keterlibatan pasien dalam perawatannya sehingga pasien merasakan kebutuhannya terpenuhi. ${ }^{29}$ Peranan terhadap kepuasan pasien pada ketrampilan setelah penerapan model pembelajaran asuhan persalinan kala I dan II terintegrasi ditunjukkan dengan keefektifan dalam melakukan pemeriksaan terhadap pasien, kemampuan melakukan pemeriksaan sesuai standar. Peranan terhadap kepuasaan pasien yang mendapat pelayanan kesehatan dari mahasiswa yaitu kemampuan memberikan pelayanan yang berpusat pada kebutuhan pasien, berkualitas dan konstribusi terhadap pelayanan kepada pasien secara profesional. ${ }^{24,30,31}$.

Mahasiswa merasakan kepuasan terhadap praktik klinik dengan penerapan pembelajaran terintegrasi ini. Peningkatan perspektif mahasiswa dalam konteks kasus nyata, mampu bersikap profesional (termasuk bahasa), peningkatan ketrampilan yang kompleks dengan pasien nyata sehingga mampu memberikan pelayanan yang holistik. ${ }^{32}$ Secara keseluruhan, kinerja bidan yang baik dipengaruhi oleh proses pendidikan yang dinilai baik. Proses pendidikan kebidanan yang ada sekarang dinilai memadai baik dilihat dari sistem pengajaran maupun dukungan sarana, salah satunya adalah pembelajaran asuhan persalinan kala I dan II terintegrasi diharapkan memberikan pelayanan yang lebih baik kepada masyarakat terutama di dalam era globalisasi. ${ }^{15}$ Model pembelajaran berbasis pengalaman di klinik ini sesuai dengan pembelajaran yang dilakukan oleh mahasiswa kedokteran yaitu kompetensi yang didapat saat masih belajar/ mahasiswa dilahan praktik memberi kesempatan menjadi tenaga kesehatan profesional, memberi pengalaman positif 58\% berpartisipasi dalam menangani pasien, lebih mandiri sehingga partisipasi mahasiswa yang optimal dapat memberikan dukungan emosional dan kepercayaan pada pasien terhadap pelayanan yang diterimanya. ${ }^{33}$

\section{Daftar Pustaka}

1. Arbayah, Mappeaty Nyorong, Syamsiar Russeng. Sikap Profesional Bidan dalam Penerapan Standar Asuhan Persalinan Normal di RSUD Harapan Insani Sendawar Kabupaten KubarBagian Promosi Kesehatan, Fakultas Kesehatan Masyarakat, Universitas Hasanuddin, Bagian Kesahatan
Keselamatan Kerja, Fakultas Kesehatan Masyarakat, Universitas Hasanuddin 2012.

2. Anggraini Y. Pengaruh Penerapan Model Pembelajaran Asuhan Persalinan Terintegrasi terhadap Pencapaian Kompetensi Mahasiswa DIII Kebidanan Bandung: Universitas Padjadjaran; 2014.

3. Putriana Y. Kompetensi Asuhan Kebidanan Komunitas Berhubungan dengan Kemampuan Bidan Melakukan Perawatan Kesehatan Masyarakat Pedesaan Stikes Karya Husada Pare. 2012;5.

4. The Royal College of Midwives. Evidence Based Guidelines for Midwifery-Led Care in Labour in Letent Phase. 2012.

5. ICM. The Philosophy and Model of Midwifery Care. Adopted at Brisbane International Council meeting 2005.

6. ICM. Essensial Competencies for Basic Midwifery Practice.2013.

7. Asadi-Lari M, Tamburini M, Gray D. Patients' needs, satisfaction, and health related quality of life: towards a comprehensive model. Health and quality of life outcomes. 2004 Jun 29;2:32. PubMed PMID: 15225377. Pubmed Central PMCID: 471563. Epub 2004/07/01. eng.

8. Kementrian Kesehatan RI. Kepmenkes No. 369/SKII/2007 tentang Standar Profesi Bidan. In: Kementrian Kesehatan RI, editor. Jakarta2007.

9. WHO, Pusdiklatnakes. Panduan Pembelajaran Praktik Klinik Kebidanan dengan Pendekatan Preceptorship dan Mentorship. Jakarta: Pusat Pendidikan dan Pelatihan Tenaga Kesehatan; 2011.

10. Adyani Asta. Analisis Pembelajaran Praktik Klinik Asuhan Kebidanan Universitas Muhammadyah Surabaya. Surakarta: Universitas Sebelas Maret; 2010.

11. Amperiana Sukma. Pengaruh Motivasi, Prestasi dan Konsep Diri terhadap Kesiapan Praktik Klinik Kebidanan Bagi Mahasiswa Tingkat II Akbid Pamenang Pare Kediri. Surakarta: Sebelas Maret; 2010.

12. Hamidah S, Palupi S. Peningkatan Soft Skills Tanggung Jawab dan Disiplin Terintegrasi melalui Pembelajaran Praktik Patiseri Jurnal Pendidikan Karakter Universitas Negeri Yogyakarta. 2012;II No. 2.

13. Department of Making Pregnancy Safer W. Technical Consultation on Postpartum and Postnatal Care. In: Safer DoMP, editor. Switzerland: World Health Organization; 2010.

14. Ghosh S, Pandya HV. Implementation of Integrated Learning Program in neurosciences during first year of traditional medical course: perception of students and faculty. BMC medical 
education. 2008;8:44. PubMed PMID: 18811978. Pubmed Central PMCID: 2569025. Epub 2008/09/25. eng.

15. Hutapea R. Determinan Kinerja dan Kompetensi Bidan di Provinsi Sumatera Utara, Nusa Tenggara Timur, Kalimantan Barat, dan Sulawesi Selatan. Kesehatan Masyarakat Nasional 2011;6, No. 1.

16. Sastroasmoro S, Ismael S. Dasar-dasar Metodologi Penelitian Klinis. 4 ed. Jakarta: Sagung Seto; 2011.

17. Isjoni., LN F. Pembelajaran terkini. 2 ed. Yogyakarta: Pustaka Pelajar; 2008. p. 62-3.

18. Chan WP, Hsu CY, Hong CY. Innovative "CaseBased Integrated Teaching" in an undergraduate medical curriculum: development and teachers' and students' responses. Annals of the Academy of Medicine, Singapore. 2008 Nov;37(11):952-6. PubMed PMID: 19082203. Epub 2008/12/17. eng.

19. Trianto. Model Pembelajaran Terpadu. Jakarta: Bumi Aksara; 2013.

20. HM J. Pembelajaran Metode Kasus. 3 ed. Yogyakarta2009.

21. Adnan, Faizal, Marliyah S. Studi Motivasi Siswa SMP dan Sederajat di Kota Makassar pada Mata Pelajaran IPA Biologi. Bionature. 2012;13(2):1037.

22. Sulistiyowati. Hubungan Minat dan Motivasi Belajar dengan Pencapaian Target Kompetensi Praktik Klinik Kebidanan Mahasiswa Prodi D3 Kebidanan Stikes Muhammadiyah Lamongan. Surakarta: Sebelas Maret 2010.

23. Uno B Hamzah. Teori Motivasi dan Pengukurannya. Jakarta: Bumi aksara; 2009.

24. Rehman R, Iqba A. Evaluation of Integrated Learning Program of Undergraduate Medical Students. Pak J Physiol 2011. 2011;7(2).

25. Drake M Susan. Menciptakan Kurikulum Terintegrasi yang Berbasis Standar. Jakarta: Indeks; 2013.

26. Suparman AM. Desain Instruktusional Modern. Jakarta: Erlangga; 2012.

27. Rezaee R, Ebrahimi S. Clinical learning environment at Shiraz Medical School. Acta medica Iranica. 2013;51(1):62-5. PubMed PMID: 23456587. Epub 2013/03/05. eng.

28. Hecimovich M, Volet S. Tracing the evolution of chiropractic students' confidence in clinical and patient communication skills during a clinical internship: a multi-methods study. BMC medical education. 2012;12:42. PubMed PMID: 22713168. Pubmed Central PMCID: Pmc3403999. Epub 2012/06/21. eng.

29. Graue M, Rasmussen B, Iversen AS, Dunning T. Learning transitions-a descriptive study of nurses' experiences during advanced level nursing education. BMC Nursing. 2015;14(1):1-9.

30. Haranath PS. Integrated teaching in medicine Indian scene. Indian journal of pharmacology. 2013 Jan-Feb;45(1):1-3. PubMed PMID: 23543941. Pubmed Central PMCID: PMC3608281. Epub 2013/04/02. eng.

31. Oda Y, Onishi H, Sakemi T, Fujimoto K, Koizumi S. Improvement in medical students' communication and interpersonal skills as evaluated by patient satisfaction questionnaire after curriculum reform. Journal of clinical biochemistry and nutrition. 2014 Jul;55(1):72-7. PubMed PMID: 25120283. Pubmed Central PMCID: PMC4078071. Epub 2014/08/15. eng.

32. Bell K, Boshuizen HP, Scherpbier A, Dornan T. When only the real thing will do: junior medical students' learning from real patients. Medical education. 2009 Nov;43(11):1036-43. PubMed PMID: 19874495. Epub 2009/10/31. eng.

33. Hay A, Smithson S, Mann K, Dornan T. Medical students' reactions to an experience-based learning model of clinical education. Perspectives on medical education. 2013 May 3. PubMed PMID: 23670698. Pubmed Central PMCID: PMC3656171. Epub 2013/05/15. Eng. 